\title{
Estimation of landfill gas production and the energy potential of municipal solid wastes from the Upper Dagong dumpsite using the Philippine Landfill Gas Model v.1
}

\author{
M. T. I. Cabaraban \& S. S. Paclijan \\ Department of Chemical Engineering, \\ Xavier University - Ateneo de Cagayan, Philippines
}

\begin{abstract}
Landfill gas (LFG) emissions are an important environmental concern in the Philippines due to the existence of several uncontrolled dump sites. LFG mostly results from the anaerobic decomposition of the biodegradable fraction, i.e. kitchen and yard wastes, in municipal solid wastes (MSW) that are disposed of in these disposal sites. This investigation was conducted to estimate the amount of LFG production and the amount of power that could be generated from the Upper Dagong dump site in Cagayan de Oro City, Philippines. This dump site started operating in 1996 and is expected to have a life span of up to 25 years. The Philippine Landfill Gas Model v.1 was used to estimate the rate of LFG generation. Model results show that the rate of LFG generation from MSW plateaued at around 2.4 $\mathrm{Mm}^{3}$ for 5 years from 2005, one year after the highest waste acceptance at the site, until 2008. The years 2004 and 2005 showed a decrease in waste acceptance rates at the dump site, but increased by around $17 \%$ in the following years. Methane generation rates could be seen to rise again from 2009 to reach its projected second peak in 2022. The power that could have been obtained from the MSW in the dump site, with 39\% LFG recovery, was estimated to be around 2.1 GWh in 2015. This provides a potential for power generation at the Upper Dagong dumpsite. Aside from generating energy, the utilization of the LFG will also create a source of revenue from the sale of certified emission reductions under the Clean Development Mechanism.
\end{abstract}

Keywords: landfill gas, methane recovery, energy availability, municipal solid waste. 


\section{Introduction}

The deposition of municipal solid wastes (MSW) on land remains the major route for control of domestic waste in much of the world [1]. Although the Philippine's Ecological Solid Waste Management Act of 2000 has called for a reduction on the amount of materials to be deposited in landfills, non-separated domestic and commercial wastes continue to be disposed of on these sites. While many throughout the Philippines have been upgraded, many existing sites continue to be operated as open dumps, where uncontrolled tipping of the wastes significantly impacts local and global greenhouse gas emissions.

It is necessary to thoroughly assess the gas resource, and hence the energy availability, of the landfill site before any landfill gas (LFG) project could be developed. The prediction of the energy availability of a landfill will provide landfill (or dumpsite) operators and managers with information to use to evaluate the feasibility and potential benefits of collecting and using the LFG generated for energy and other uses.

Biogas typically refers to a gas produced from the fermentation of organic matter in the absence of oxygen. It contains $45-60 \%$ of methane $\left(\mathrm{CH}_{4}\right)$ by volume, with the rest being mainly carbon dioxide $\left(\mathrm{CO}_{2}\right)$ and a trace amount of hydrogen sulfide $\left(\mathrm{H}_{2} \mathrm{~S}\right)$, nitrogen, ammonia, sulfur dioxide and carbon monoxide. When biogas is produced from the organic waste disposed of in a landfill, it is referred to as LFG.

The design of most controlled dumps does not include technology to promote biodegradation through the injection of water, oxygen, and even microbes. In the environment of most controlled dumps, the breakdown of solid waste containing organic carbon can be written as

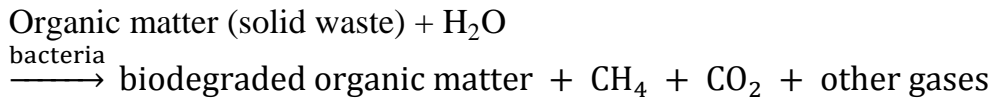

The uncontrolled processes of biomass decay in dumps use a series of microbiological process to degrade and stabilize the decomposable organic waste. The bacteria that aid in the decomposition do not require oxygen (i.e. anaerobic). The decomposition processes, however, require the presence of water. Consequently, although the total LFG generated from solid waste decomposition derives from this reaction stoichiometry, local hydrologic conditions affect significantly the rate and the period of time over which gas production takes place [2]. Besides the quantity, the quality of the gas produced also varies by each landfill site.

The gases generated by the decomposing solid wastes would continue to be released into the atmosphere several decades after the last load of garbage is dumped. $\mathrm{CH}_{4}$ is a potent greenhouse gas - 21 times more efficient at trapping infrared radiation from the earth's surface than carbon dioxide $\left(\mathrm{CO}_{2}\right)$ [3]. Remaining in the atmosphere for 9-15 years, it also contributes to ozone loss. Emission controls that capture and utilize landfill $\mathrm{CH}_{4}$ are an effective reduction 
strategy. In addition to reducing greenhouse gas emissions, collecting the LFG will improve the air quality of the surrounding community by reducing landfill odors, reduce potential health risks from organic compounds present in LFG, and improve landfill safety by reducing explosion hazards from gas accumulation.

The present study focused particularly on the LFG production from an actual controlled dumpsite under tropical climatic environmental conditions. Specifically, the study was to determine solid waste characteristics and their relationship to LFG production. The results are expected to provide additional information that might spur legislative and administrative measure to overcome financial and non-financial obstacles to the use of LFG to minimize the emission of greenhouse gases. LFG-to-energy projects make possible the generation of revenue from the sales of power generated and/or high-BTU gas produced.

\subsection{The MSW dump site}

The controlled dump (Figure 1) in Upper Dagong in Carmen, Cagayan de Oro City is located only $3.5 \mathrm{~km}$ from the city center. The $135,000-\mathrm{m}^{2}$ facility, which started operations in 1996, has a capacity of 1.9 million cubic meters. At present, a little more than half of the land area (around $80,000 \mathrm{~m}^{2}$ ) is active dump site. Wastes dumped on the site are spread, compacted, and covered with a thin layer of soil thereby exposing the compacted wastes to the elements. However, these activities happen sporadically, due to insufficient number of equipment available. At present, operation involving LFG is limited to its intermittent flaring from two gas vents that are currently operating. Controlled waste picking and trading also take place within the facility.

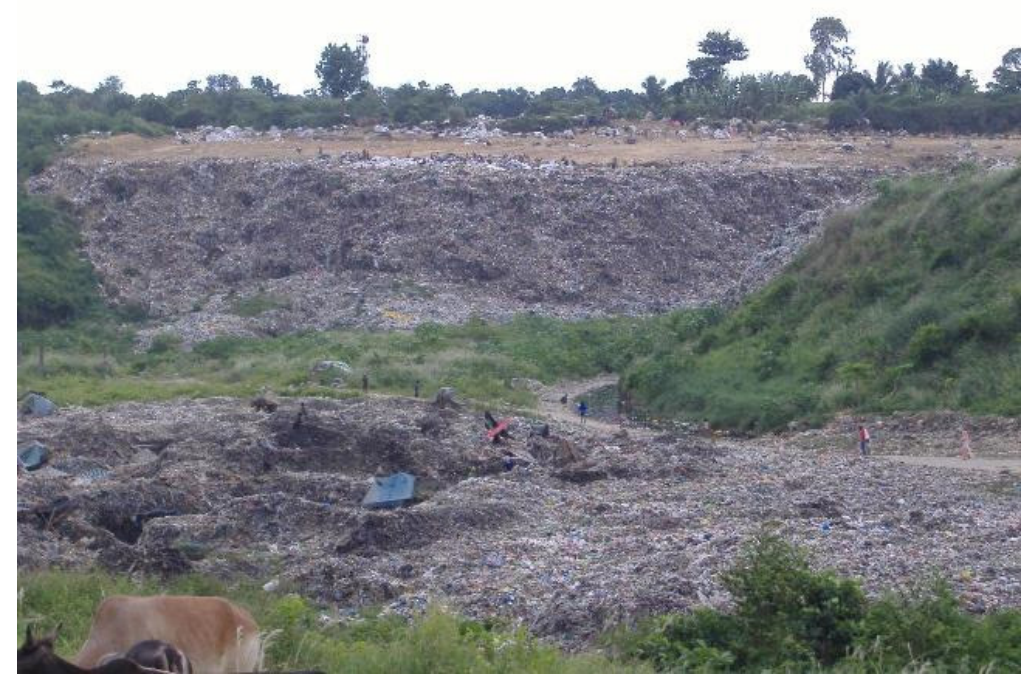

Figure 1: The city dumpsite located at Upper Dagong, Cagayan de Oro City. 
Table 1 shows the yearly quantities of disposed wastes in the period 1996 to 2005. A large portion of the wastes in the dump site is biodegradable, represented by large amounts of food and kitchen wastes (44\%), and garden and yard wastes (28\%); other wastes also present are paper and cardboard (5\%), plastics (9\%), wood (2\%), textile (7\%), and other inorganics (5\%) [4]. The wastes contained a high moisture content of $81 \%$.

Table 1: Yearly disposed quantities of MSW in Upper Dagong dump site, 1996-2005.

\begin{tabular}{|c|c|}
\hline Year & Total MSW collected* $\mathbf{( m}^{\mathbf{3}} \mathbf{)}$ \\
\hline 1996 & $134,378.8$ \\
\hline 1997 & $141,087.7$ \\
\hline 1998 & $174,594.7$ \\
\hline 1999 & $219,387.0$ \\
\hline 2000 & $268,782.5$ \\
\hline 2001 & $294,921.0$ \\
\hline 2002 & $306,556.5$ \\
\hline 2003 & $310,810.7$ \\
\hline 2004 & $265,617.4$ \\
\hline 2005 & $200,307.5$ \\
\hline * Data obtained from City Public Services Office (CPSO). \\
\hline
\end{tabular}

The climate in Cagayan de Oro City is of tropical, fully humid type with a mean annual precipitation of approximately 2,450 $\mathrm{mm}$ [5] and monthly evaporation of $3.8 \mathrm{~mm}$ [6]. The rainy or wet season lasts from June until November, while the relatively drier season lasts from December until May. The monthly average ambient temperature ranges from $23^{\circ} \mathrm{C}$ (from November until March) to $34^{\circ} \mathrm{C}$ (in April and May).

\section{Materials and methods}

\subsection{Modelling of LFG generation}

The Philippine Landfill Gas Model v.1, developed on behalf the US Environmental Protection Agency's (EPA's) Landfill Methane Outreach Program, is an automated estimation tool with a Microsoft Excel interface that can be used to estimate generation rates for LFG, and rates for potential LFG recovery for landfills that have, or plan to have, gas collection and control systems in the Philippines [7]. The model is based on a first-order decomposition rate equation for quantifying the emissions over a user-defined time period using the amount of MSW deposited and the $\mathrm{CH}_{4}$ generation capacity. The Philippine LFG model methodology can be described mathematically by eqn (1):

$$
\mathrm{Q}_{\mathrm{M}}=\frac{1}{\mathrm{C}_{\mathrm{CH}_{4}}} \sum_{i=1}^{n} \sum_{j=0.1}^{1} \mathrm{~kL}_{\mathrm{o}}\left(\frac{\mathrm{M}_{\mathrm{i}}}{10}\right) \mathrm{e}^{-\mathrm{k} \mathrm{t}_{\mathrm{ij}}}
$$


where $\mathrm{Q}_{\mathrm{M}}=$ maximum expected LFG generation flow rate $\left(\mathrm{m}^{3}\right.$ year $\left.^{-1}\right)$, $\mathrm{C}_{\mathrm{CH} 4}=$ methane concentration (volume fraction), $\mathrm{i}=1$ year time increment, $\mathrm{n}=$ (year of the calculation) - (initial year of waste acceptance), $\mathrm{j}=0.1$ year time increment, $\mathrm{k}=$ methane generation rate $\left(\mathrm{year}^{-1}\right), \mathrm{L}_{\mathrm{o}}=$ ultimate $\mathrm{CH}_{4}$ generation potential $\left(\mathrm{m}^{3} \mathrm{Mg}^{-1}\right), \mathrm{M}_{\mathrm{i}}=$ mass of solid waste disposed in the $\mathrm{i}^{\text {th }}$ year $(\mathrm{Mg})$, and $t_{i j}=$ age of the $j^{\text {th }}$ section of waste mass disposed in the $i^{\text {th }}$ year (decimal years).

Eqn (1) is used by the USEPA's Landfill Gas Emissions Model (LandGEM) version 3.02 [8]. Site-specific inputs to the model include opening and closing years, refuse disposal rates, history of landfill fires, and other landfill characteristics that determine LFG collection efficiency. Based on these sitespecific data, the model was run to estimate the LFG generation rates of a new landfill gas-to-energy project, with parameters $k=0.18$ year ${ }^{-1}$ and $L_{0}=60 \mathrm{~m}^{3} \mathrm{Mg}$ ${ }^{1}$. The recommended method for estimating the LFG collection efficiency assumes that at least $15 \%$ of the generated gas will escape collection [7]. Subsurface fires had been reported to have billowed at the site [9]. Since landfill fires can consume a significant amount of organic matter, thereby drastically reducing the LFG generation rate, the model was run with a fire discount factor $=30 \%$. The model further reduced the LFG collection efficiency based the on construction and operation at the site. The LFG system area coverage was estimated to be equal to $40 \%$, i.e. the percentage of the landfilled area that has a comprehensive and operating LFG collection system. Hence, the model used an effective LFG collection efficiency of $39 \%$ before the site closure, and $65 \%$ subsequently [7].

\section{Results and discussion}

\subsection{LFG generation from Upper Dagong dump site}

A projection of the LFG generation up to 2095 was done for the Upper Dagong dump site. The annual LFG production profile predicted by the Philippine LFG model is presented in Figure 2. The graph shows that the amount of LFG will keep on increasing until it reaches the peak LFG generation in 2022, the year after the expected closure of the dump site, when an estimated rate of $3 \mathrm{Mm}^{3}$ of LFG would be generated. However, with the current design of the dump site, the estimated peak amount of LFG that could be captured was only $2 \mathrm{Mm}^{3}$. After 2022, when no more waste would be expected to be placed in the present available space, the LFG would continue to be produced, but the generation rates would decrease exponentially.

\subsection{LFG energy potential}

The goal of this analysis is to determine the amount of electric energy that is potentially available in the Upper Dagong dump site. The Philippine LFG model also estimates potentially available energy output from a power generation project. Assuming that the LFG is burned in an engine with $30 \%$ efficiency to produce electricity, the model estimated a maximum energy potential of the recovered LFG 


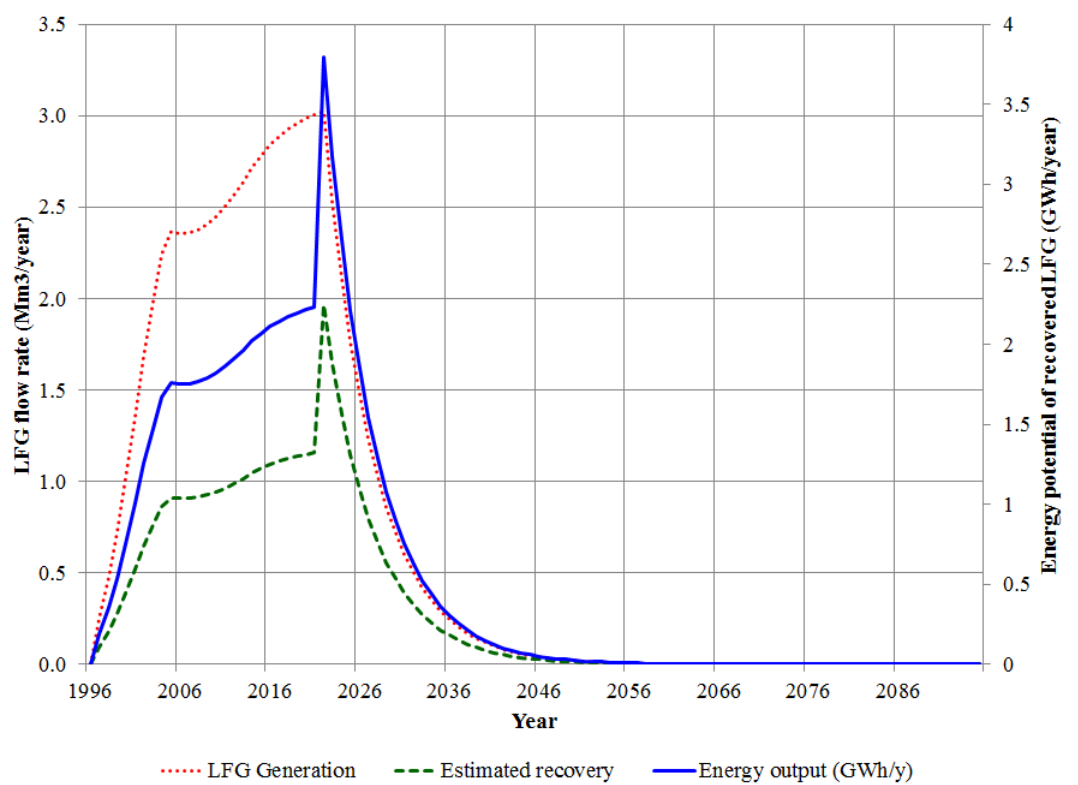

Figure 2: Annual LFG production estimated by the Philippine LFG model for Upper Dagong dump site, Philippines.

of $3.8 \mathrm{GWh}$ during the year 2022, when peak LFG production is expected. If the project were to commence in 2015, the recovered LFG would generate around 2 GWh of electricity during that year. By 2029, at the end of a 15-year useful project life, it would be sufficient to generate around $1 \mathrm{GWh}$ of electricity. On the other hand, a direct-use LFG energy project that burns the LFG in a boiler with $85 \%$ efficiency to produce steam would generate $4.54 \times 10^{3} \mathrm{MJ} \mathrm{hr}^{-1}$ of energy.

Capital cost of the LFG-to-energy project was estimated at around PHP $20 \mathrm{M}$ $(\$ 454,500)$. To make the LFG recovery feasible without subsidies, the generated electricity should be sold at PHP 5.00/kWh ( $\$ 0.11 / \mathrm{kWh})$ or higher. The beneficial use of LFG as an energy resource can reduce methane emissions to the atmosphere and offset the use of fossil fuels. The total reduction of LFG emitted directly from the site over a 15-year lifetime, from 2015 to 2029, would be around 153 GT of $\mathrm{CO}_{2}$ equivalent. If emission reductions were to be traded and sold under the Clean Development Mechanism at PHP 439 (\$10) per MT of $\mathrm{CO}_{2}$ equivalent, the estimated revenue from carbon credit would be about PHP 80.7 M (\$1.8 M) over the project's 15-year lifetime. Accounting for carbon credit, the electricity generated could be sold at PHP 2.64/kWh $(\$ 0.06 / \mathrm{kWh})$.

\section{Conclusion}

Landfills are known to be a source of greenhouse emissions, which could be mitigated if LFG were recovered from the landfill. In this study, LFG generation 
from the Upper Dagong dump site was estimated using the Philippine LFG model v.1. It was estimated that the amount of LFG generated in the year 2022, at the projected closure of the dump site, will be $3 \mathrm{Mm}^{3}$, while the power that can be obtained from the dump site if LFG were recovered will be $3.8 \mathrm{GWh}$. Total reduction of $\mathrm{CO}_{2}$ to the atmosphere is $153 \mathrm{GT}$ over al 15-year LFG-to-energy project lifetime, commencing in 2015. With market trading of $\mathrm{CO}_{2}$ emission reduction credits, this could generate additional revenue for the waste-to-energy project. It is recommended to carry out a field study by conducting probing trials or pump tests to validate the results of the LFG modeling.

\section{References}

[1] Predictions and projections. Waste Management World (WMW). Online www.waste-management-world.com/.../predictions-and-projections.htm

[2] Tchobanoblous, G., Theisen, H., \& Vigil, S., Integrated Solid Waste Management: Engineering Principles and Management Issues, McGrawHill, New York, NY, 1993.

[3] Overview of greenhouse gases: Methane emissions. US Environmental Protection Agency (EPA). Online http://epa.gov/climatechange/ghgemissions/gases/ch4.html

[4] Ayco, R., Cabanlit, R.J., Satorre, M.J., \& Tirando, J., Development of a methane gas purification system using pressure swing absorption (baby thesis). Xavier University, Cagayan de Oro City, pp. 1-166, 2009.

[5] Hourly global surface data (2011-2012). National Climatic Data Center (NCDC). Online http://www.ncdc.noaa.gov/cdo-web/

[6] Palanca-Tan, R., Designing a raw water fee scheme for groundwater extraction in Cagayan de Oro City, Philippines. EEPSEA publications, 2011.

[7] User's manual: Philippine landfill gas model v.1. US Environmental Protection Agency (EPA). Online http://iesmanila.com/lgis/content/philippine-landfill-gas-model

[8] Alexander, A., Burklin, C., Singleton, A., Landfill gas emissions model (LandGEM) version 3.02 user's guide. EPA-600/R-05/047, 1-56, 2005.

[9] Jerusalem, J., City to form solid waste management board. Sun Star Cagayan de Oro, April 2, 2014. Online http://www.sunstar.com.ph/cagayan-de-oro/local-news/2014/04/02/cityform-solid-waste-management-board-336200 